Viewpoints and Letters to the Editor are published in Hoi-t- comments on matters of concern to horticulturists. These are Science to provide members of the American Society for Her- not statements of official Society policy nor do they necessarticultural Science an opportunity to share their experiences and ily reflect the views of a majority of the Society's members.

\title{
Tomato Evolution and Its Implications for Tomato Culture
}

\author{
S.J. Warnock \\ Campbell Institute for Research and Technology, Route 1, Box 1314, Davis, CA 95616
}

It is generally agreed that the genus Lycopersicon evolved in western South America. The natural distribution of the eight strictly wild species is confined to this area (Rick, 1976). The wild form of L. esculentum is also native to this area, but has spread to other areas of Latin America. While the location of domestication is not certainly established, the most plausible explanation is that L. esculentum var. cerasiforme dispersed to Mexico (and much of the rest of Latin America) as a weedy form and subsequently was domesticated there (Jenkins, 1948). Rick and Fobes (1975) suggested that evolution of modern tomato cultivars followed from a hypothetical phylogeny precursor to L. esculentum var. cerasiforme to domestication in Mexico to the present largefruited cultivars. Shortly after the Spanish Conquest, L. esculenturn was carried to Europe and then throughout the world. Hence, our modern tomato cultivars, while not necessarily arising directly in the center of origin, have their root beginnings on the west coast of Latin America.

Improvement of crop yields through genetic betterment has been a major thrust in scientific research in agriculture, and plant breeding for stress environments has had major focus in recent years (Blum, 1988; Christiansen and Lewis, 1982). Genetic improvement has been based on Mendelian diversity. Rick (1978) has indicated that an idea of the nature of genetic value of a collection can be obtained from the habitat in which the collection was made. For example, L. cheesmanii types that have salt tolerance have been collected in the littoral zone in the Galapagos. Drought-tolerant L. pennellii and $L$. chilense types from the west slope of the Andes have been described. Biotypes of L. esculentum var. cerasiforme that withstand wet conditions have been found in tropical rainforests of Ecuador. Cold-tolerant $L$. chilense and L. hirsutum types have been found in the Andes above $3000 \mathrm{~m}$.

Received for publication 16 Dec. 1988. The cost of publishing this paper was defrayed in part by the payment of page charges. Under postal regulations, this paper therefore must be hereby marked advertisement solely to indicate this fact.
Perhaps equally as important, but considerably less-emphasized, is the fact that tomato crop production appears to have been improved by matching the production environment and conditions to the conditions under which Lycopersicon evolved. Tomato yields in California have increased steadily as management practices there have paralleled the environmental conditions that tomatoes have been exposed to in their wild habitat. Improvement in this vein has been based on the genetic similarities of the domestic and related wild species.

Tomatoes evolving on the west coast of South America were subjected to local weathe conditions of the Andes. The prevailing winds at the low latitudes of this area are from the east and moisture is carried inland from the Atlantic Ocean. Storms carried by these winds sweep across the Brazilian Shield and eventually are drained of their moisture by the high Andes. As a result of this westerly flow of Atlantic marine air, most of the west coast of South America in the low latitudes south of the equator is in a rain shadow. Rain shadows also occur in some of the interAndean valleys. Rainfall from Pacific marine air is practically nonexistent.

While the coastal area is arid from a meteorological standpoint, it is characterized by numerous small rivers that flow on a westerly course out of the Andes into the Pacific Ocean. These rivers receive water on their watersheds from the westerly flowing storms that crest the vertex of the Andes. This rainfall varies in intensity throughout the year. Normally, highest rainfall occurs from October through March. Rivers tend to rise to flood stage in the late spring and early summer (December-February south of the equator). As a result of this flooding, the valleys and small coastal deltas at the mouth of these rivers were periodically inundated before the advent of man, and still may be if protection from flooding is inadequate. Aquifers are replenished and groundwater maybe relatively close to the surface. Tomato seed germinates as a result of this moisture, and germination of affected seed is relatively rapid because of warm weather. Eventually, the water level recedes, but growth continues to maturity as roots continue to extract moisture from greater soil depths.
Fog also plays a roll in development of some wild tomato species. Fogs generally are heaviest at the end of winter and in the early spring (August to October), when the Peru Current is the coldest. Condensate on rocks in the vicinity of soil and on soil provides moisture for germination and growth of tomato seed. In this type of environment, the tomato is subjected to available nutrients early on in its development, with these probably being restricted as the moisture dries down and the crop matures. Nitrogen, in particular, would be unavailable in dry soils.

Seed dispersal comes about in various ways. Rhagoletis Iycopersella the Peruvian tomato fly, occurs on the west coast of South America (Smyth, 1960) and appears to be indigenous (Bush, 1966). This insect lays its eggs under the skin of the tomato fruit in the green stage. The small larvae bore into the fruit and develop internally. Just as the fruit reaches first blush, the larvae emerge and the resultant opening permits the entrance of yeasts. These yeasts then ferment the contents of the tomato fruit in the natural sac formed by the skin; subsequently, the seeds and skin together fall to the ground and the seeds germinate during the next flood season. The seed from ripe fruit of species may also be dispersed singly or in small groups by birds or the desert fox, which apparently use the tomato as a source of water as well as food.

It is interesting to note that, as cultural practices in California have changed to more closely parallel development in the wild, yields have consistently increased. Yields in the early 1950 s were $\approx 30 \mathrm{t} \cdot \mathrm{ha}^{-1}$. Present yields average $>55 \mathrm{t} \cdot \mathrm{ha}^{-1}$. For many years, tomatoes in California were transplanted. Plants were put out from April through May. With a desire for higher populations and earlier seeding, there was an increase in the mid-1950s of direct seeding with a relatively wide spacing between plants in the row. With the advent of machine harvesting, pressure became greater for higher populations. It was found that tomatoes could be rather closely spaced and actually grown in clumps, similar to what one would expect under their normal evolution where the entire tomato sac fell to the ground and there was incomplete dispersal of seed. 
Machine harvest also put pressure on irrigation practices. Termination of irrigation well-ahead of the advent of harvest was desirable. It was soon found that this could be done with no noticeably detrimental effects to tomatoes, and perhaps with an increase in solids. Tomatoes responded well to this type of management because this is a normal event in wild tomato development under their native milieu.

During investigations in Peru (unpublished data), seedings of tomatoes were made monthly throughout the year. There was a marked difference in solids content of the fruit in these seedings, with the highest solids being in those tomato crops that were seeded and had. their early growth during the warm summer months and subsequently matured during fall weather. Differences in solids content related to seeding has occurred in California as direct-seeded tomatoes have become more common. Tomatoes may be planted as early as January, i.e., in cold weather. In many years this seasonality is apparently reflected in the tomato processing plant, where low solids are reported early in the season but tend to rise as production comes from the later-seeded crops. This relationship suggests that there is a connection between solids content of tomatoes and the temperature at the time of seeding or during the early growing period.

It has further been our experience at Campbell that the best rate of growth has been obtained when tomatoes receive light, frequent irrigations that are terminated wellahead of harvest. Tomatoes tend to prosper under drip irrigation - this is reminiscent of the natural irrigation under foggy or misty conditions. Tomatoes tend to respond best to early applications of fertilizer with little response to late applications, particularly nitrogen (unpublished data). This phenomenon would be related to the low available water supply and dry-down experienced in wild tomato development late in the season.

A management strategy that recognizes the native habitat as well as specifically bred traits and uses both in management practice will be the most successful.

\section{Literature Cited}

Blum, A. 1988. Plant breedirrg for stress environments. CRC Press, Boca Raton, Fla.

Bush, G.L. 1966. The taxonomy, cytology, and evolution of the genus Rhagoletis in North America (Diptera, Tephritidae). Bul. Museum Comp. Zool. 134:431-525.

Christianson, M.M. and C.F. Lewis (eds.). 1982. Breeding plants for less favorable environments. Wiley, Somerset, N.J.

Jenkins, J.A. 1948. The origin of the cultivated tomato. Econ. Bet. 2:379-392.

Rick, C.M. 1976. Tomato Lycopersicon esculentum (Solanaccae), p. 268-273. In: N.W. Simmonds (cd.). Evolution of crop plants. Longman, London.

Rick, C.M. 1978. Potential genetic rcsources in tomato species: Clues from observations in native habitats, p. 255-269. In: A.M. Srb (cd.). Genes, enzymes, and populations. Plenum, New York.

Rick, C.M. and J.F. Fobcs. 1975. Atlozyme variation in the cultivated tomato and closely relatcd species. Bul. Torrey Bet. Club 102:376384.

Smyth, E.G. 1960. A new tephritid fly injurious to tomatoes in Peru. Calif. Dept. Agr. Bul. 49:16-22. 